\title{
Vegetation Gradients of Forests in Northwestern Kitakyushu City and Nearby Areas
}

\author{
Syuzo ITOW ${ }^{1}$, Nobumitsu JINNO ${ }^{2}$, Yuzo KITAZAWA ${ }^{3}$ and Toshio YAMAKI ${ }^{3}$ \\ 'Plant Ecology Laboratory, Nagasaki University. Nagasaki 852, Japan \\ ${ }^{2}$ Department of Biology, Fukuoka University of Education. Akama 811-41, Japan \\ ${ }^{3}$ Department of Biology, University of Occupational and Environmental Health, Japan. \\ Kitakyushu 807, Japan
}

Abstract: Fifty forest stands and sixty plant species were ordinated by a reciprocal averaging (RA) method to extract the major vegetation patterns of the forest in northwestern Kitakyushu City and nearby areas. The RA stand ordination on the first and second axes revealed three gradients of vegetation. They are the gradients (1) from the Quercus serrata-dominated forest to the Machilus thunbergii- or Aphananthe aspera-dominated forest, (2) from the Quercus- to the Castanopsis cuspidata-dominated forest, and (3) from the Aphananthe- or the Machilus- to the Castanopsis-dominated forest. The first two gradients showed high correlations of the stand RA scores to the canopy height and to the number of species found in the stand, but the third one did not. The former two, therefore, were referred to as the successional series of forests on the moist (bottomland) habitat and that on the less moist (foothill) one, respectively, and the third as the environmental gradient from moist to less moist habitats in matured forests. The RA species ordination showed the distribution center of each species in the above mentioned patterns of the forest vegetation.

Key words: Aphananthe-Celtis forest, environmental gradient, forest succession, ordination, reciprocal averaging.

(Received 15 February 1984)

\section{Introduction}

Our vegetation studies in the Kitakyushu City area started in 1980, as a part of the environmental studies of the area, to describe the existing, actual plant-communities, to clarify the original vegetation on various habitats (that have been converted to the presentday agricultural, residential and industrial areas), and to find the general vegetationhabitat patterns. Our previous paper (Itow et al., 1981) described, as a first step, the outline of the vegetation with some notes on conservation. The present paper is the second one of our vegetation studies describing the vegetation patterns found in the existing forest communities. 


\section{Study Area and Methods}

Study area

The area of the present study, as described in the previous paper (Itow et al., 1981), comprises Yawata-nishi and Wakamatsu Wards of Kitakyushu City and the nearby towns in northern Kyushu. The forest tracts studied are all located in lowland and hilly areas, lower than $100 \mathrm{~m}$ in altitude, except for two stands. Climatically, the whole study area is in the warm-temperate region. The mean annual temperature ranges from 14 to $15^{\circ} \mathrm{G}$, the mean temperature of the coldest month (January) is between 4 and $5^{\circ} \mathrm{G}$ and that of the warmest month (August) between 25 and $26^{\circ} \mathrm{C}$. The annual precipitation is about $1800 \mathrm{~mm}$, including a small amount of snowfall in winter. Ecologically, the area is in the laurel-leaf, or evergreen broadleaf, forest climax region. The maritime forest and scrub are found along the coast but they are excluded from the present paper.

The forest stands studied are distributed separately in well-developed agricultural, industrial, and residential area. Many of them are the precincts of Shinto-shrines in towns and villages. Some are found near Buddist temples. The stands studied totalled fifty in number (Table 1 and Fig. 1).

The trees of the stands were sparsely or densely spaced, covering 40 to 90 per cent of the ground, being accompanied by dense growth of shrubs and herbs. The dominant species of the forest canopy is one of the following species: Castanopsis cuspidata (including var. sieboldii) (Fagaceae), Quercus serrata (Fagaceae), Machilus thunbergii (Lauraceae), Cinna-

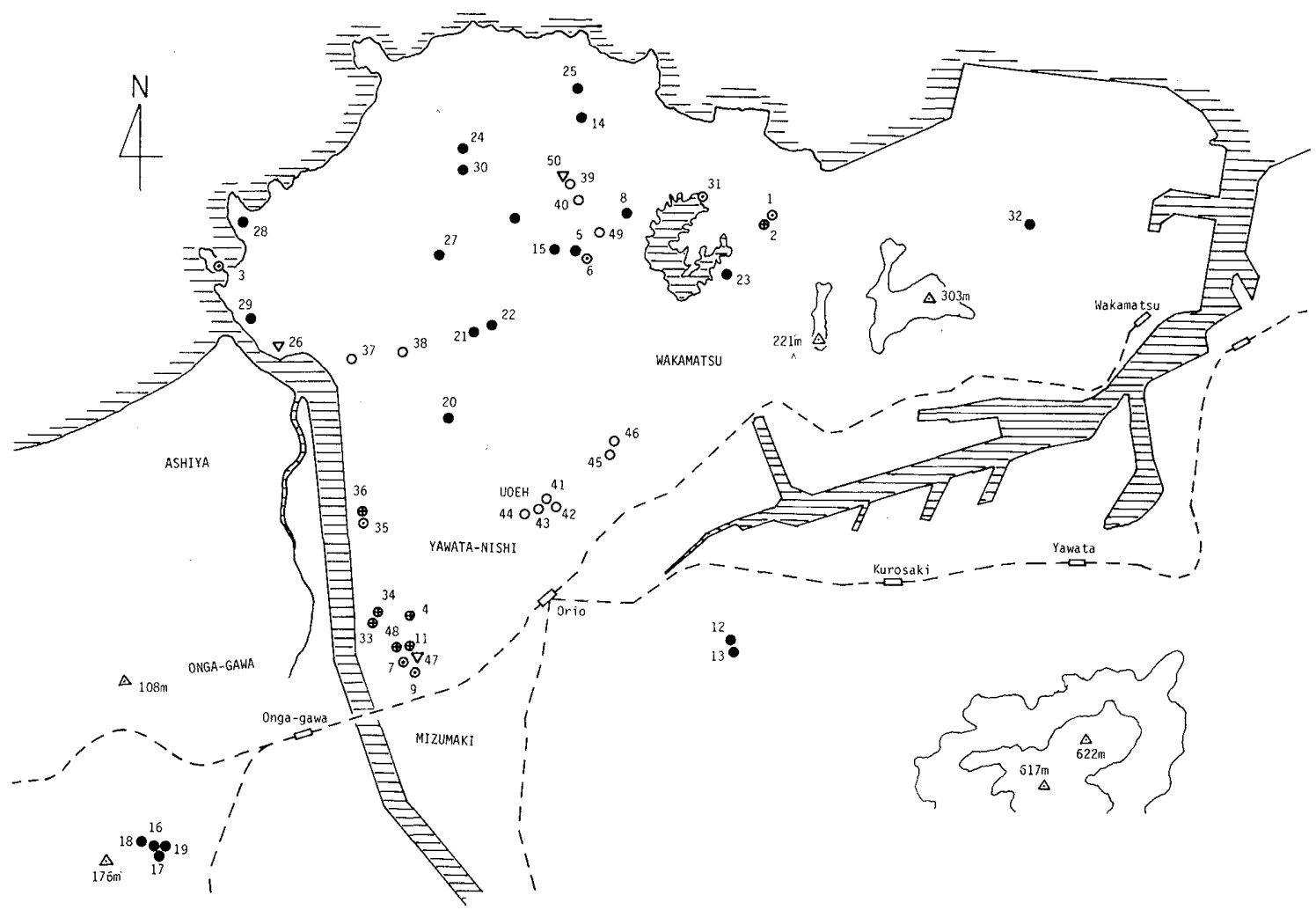

Fig. 1. Map of northwestern Kitakyushu City and nearby area, showing the location of the forest stands studied. Numerals are the stand numbers listed in Table 1. 
Table 1. List of the stands studied with their altitude $(\mathrm{m})$, canopy height $(\mathrm{m})$, total number of species recorded (A), number of species excluding those occurred in one or two of the fifty stands (B), and RA scores on first and second axes. Abbreviations for dominants and subdominants are as follows: Apa. Aphananthe aspera, Cac. Castanopsis cuspidata, including var. sieboldii, Ces. Celtis sinensis var. japonica, Cic. Cinnamomum camphora, Cij. Cinnamomum japonicum, Cyg. Cyclobalanopsis gilva, Els. Elaeocarpus sylvestris, Ilr. Ilex rotunda, Maj. Mallotus japonicus, Mat. Machilus thunbergii, Mer. Meliosma rigida, Mic. Michelia compressa, Pid. Pinus densiflora, Prj. Prunus jamasakura, Qus. Quercus serrata, Zaa. Zanthoxylum ailanthoides

\begin{tabular}{|c|c|c|c|c|c|c|c|}
\hline \multirow[b]{2}{*}{ Locality } & \multirow{2}{*}{$\begin{array}{l}\text { Altitude } \\
(\mathrm{m})\end{array}$} & \multirow{2}{*}{$\begin{array}{l}\text { Dominant and } \\
\text { subdominant }\end{array}$} & \multirow{2}{*}{$\begin{array}{c}\text { Canopy } \\
\text { height }(\mathrm{m})\end{array}$} & \multicolumn{2}{|c|}{ No. of spp. } & \multicolumn{2}{|c|}{ RA score } \\
\hline & & & & (A) & (B) & 1st axis & 2nd axis \\
\hline 1) Hakusan S.; Kotake; Wa. & 180 & Mat / Mic & 25 & 64 & 60 & 95 & 34 \\
\hline 2) Hakusan S.; Kotake; Wa. & 150 & Apa / Mat & 25 & 61 & 56 & 95 & 29 \\
\hline 3) Hiruko S.; Kashihara; Ashiya & 20 & Mat & 13 & 42 & 38 & 58 & 26 \\
\hline 4) Ooyamazumi S.; Mizumaki & 70 & Mat / Cac & 20 & 55 & 53 & 100 & 5 \\
\hline 5) Suga S.; Takenami; Wa. & 40 & Cyg / Cac & 20 & 60 & 55 & 90 & 74 \\
\hline 6) Suga S.; Takenami; Wa. & 40 & $\mathrm{Cac} / \mathrm{Mer}$ & 25 & 22 & 20 & 95 & 33 \\
\hline 7) Izu S.; Mizumaki & 80 & Mat / Cac & 15 & 39 & 39 & 100 & 40 \\
\hline 8) Reservior 2; Tonda; Wa. & 30 & $\mathrm{Cac}$ & 18 & 56 & 55 & 69 & 68 \\
\hline 9) Izu S.; Mizumaki & 40 & $\mathrm{Cac} / \mathrm{Mat}$ & 12 & 43 & 42 & 89 & 27 \\
\hline 10) Kamigumi; Wa. & 20 & $\mathrm{Cac}$ & 15 & 31 & 31 & 72 & 50 \\
\hline 11) Tsukue; Mizumaki & 90 & Mat / Cac & 18 & 40 & 39 & 99 & 0 \\
\hline 12) Kozenji T.; Anao; Ya. & 20 & $\mathrm{Cac}$ & 15 & 35 & 34 & 87 & 66 \\
\hline 13) Kozenji T.; Anao; Ya. & 20 & $\mathrm{Els} / \mathrm{Cac}$ & 25 & 33 & 32 & 97 & 42 \\
\hline 14) Hiyoshi S.; Nakatani; Wa. & 30 & $\mathrm{Cac}$ & 17 & 57 & 55 & 78 & 77 \\
\hline 15) Toake S.; Amazumi; Wa. & 30 & $\mathrm{Cac} / \mathrm{Mat}$ & 15 & 39 & 39 & 74 & 72 \\
\hline 16) Handa; Onga & 20 & $\mathrm{Cac} / \mathrm{Mat}$ & 20 & 72 & 62 & 73 & 73 \\
\hline 17) Handa; Onga & 30 & $\mathrm{Cac} / \mathrm{Mat}$ & 18 & 60 & 55 & 73 & 79 \\
\hline 18) Handa; Onga & 40 & $\mathrm{Cac}$ & 20 & 42 & 41 & 75 & 85 \\
\hline 19) Handa; Onga & 20 & $\mathrm{Cac} / \mathrm{Mat}$ & 20 & 49 & 48 & 71 & 88 \\
\hline 20) Nakao S.; Takasu; Wa. & 15 & $\mathrm{Cac}$ & 10 & 34 & 32 & 66 & 52 \\
\hline 21) Myosenji T.; Ootorii; Wa. & 30 & $\mathrm{Cac} / \mathrm{Mat}$ & 18 & 48 & 47 & 58 & 66 \\
\hline 22) Toake S.; Ootorii; Wa. & 25 & $\mathrm{Cac} / \mathrm{Mat}$ & 15 & 41 & 41 & 44 & 68 \\
\hline 23) Reservior 1; Tonda Wa. & 50 & $\mathrm{Cac} / \mathrm{Mat}$ & 10 & 41 & 41 & 58 & 75 \\
\hline 24) Toake S.; Hakomaru; Wa. & 40 & $\mathrm{Cac} / \mathrm{Mat}$ & 20 & 48 & 48 & 66 & 85 \\
\hline 25) Ushiro; Wa. & 25 & $\mathrm{Cac} / \mathrm{Mat}$ & 10 & 42 & 40 & 69 & 75 \\
\hline 26) Yamaga; Ashiya & 30 & $\mathrm{Cij}$ & 10 & 44 & 44 & 83 & 49 \\
\hline 27) Towaki S.; Oda; Wa. & 30 & $\mathrm{Cac} / \mathrm{Mat}$ & 15 & 35 & 35 & 59 & 68 \\
\hline 28) Kario S.; Ashiya & 30 & $\mathrm{Cac} / \mathrm{Mat}$ & 18 & 36 & 36 & 67 & 100 \\
\hline 29) Giongu S.; Ashiya & 30 & $\mathrm{Cac} / \mathrm{Mat}$ & 15 & 28 & 28 & 82 & 77 \\
\hline 30) Jugosha S.; Arige; Wa. & 20 & $\mathrm{Cac} / \mathrm{Mat}$ & 18 & 48 & 45 & 92 & 61 \\
\hline 31) Reservior 2; Tonda; Wa. & 40 & $\mathrm{Cac} / \mathrm{Mat}$ & 10 & 27 & 27 & 71 & 29 \\
\hline 32) Sakota; Wa. & 90 & $\mathrm{Il} r / \mathrm{Cac}$ & 10 & 55 & 49 & 48 & 58 \\
\hline 33) Kuga S.; Mizumaki & 50 & Apa & 12 & 43 & 36 & 95 & 16 \\
\hline 34) Kuga S.; Mizumaki & 40 & Apa / Ces & 20 & 53 & 42 & 91 & 14 \\
\hline
\end{tabular}




\begin{tabular}{|c|c|c|c|c|c|c|c|}
\hline \multirow[b]{2}{*}{ Locality } & \multirow{2}{*}{$\begin{array}{l}\text { Altitude } \\
(\mathrm{m})\end{array}$} & \multirow{2}{*}{$\begin{array}{l}\text { Dominant and } \\
\text { subdominant }\end{array}$} & \multirow{2}{*}{$\begin{array}{c}\text { Canopy } \\
\text { height (m) }\end{array}$} & \multicolumn{2}{|c|}{ No. of spp. } & \multicolumn{2}{|c|}{ RA score } \\
\hline & & & & (A) & (B) & 1st axis & 2nd axis \\
\hline 35) Takami S.; Mizumaki & 30 & $\mathrm{Apa} / \mathrm{Ces}$ & 20 & 51 & 49 & 93 & 16 \\
\hline 36) Takami S.; Mizumaki & 30 & Apa / Ilr & 20 & 40 & 40 & 96 & 44 \\
\hline 37) Ookimi S.; Ashiya & 40 & Qus / Apa & 10 & 39 & 38 & 47 & 21 \\
\hline 38) Saruwatari; Ya. & 20 & Qus & 8 & 57 & 47 & 27 & 34 \\
\hline 39) Takenami; Wa. & 40 & Qus / Pid & 6 & 38 & 35 & 23 & 33 \\
\hline 40) Takenami; Wa. & 30 & Qus / Pid & 6 & 29 & 24 & 0 & 14 \\
\hline 41) Ryugaike; UOEH & 50 & Qus & 8 & 35 & 35 & 6 & 13 \\
\hline 42) Ryugaike; UOEH & 50 & Qus $/ \mathrm{Zaa}$ & 6 & 23 & 22 & 0 & 15 \\
\hline 43) Nurse's Dorm; UOEH & 50 & Qus / Zaa & 8 & 40 & 35 & 14 & 26 \\
\hline 44) Water Supply Facil.; UOEH & 30 & Qus & 10 & 36 & 33 & 61 & 44 \\
\hline 45) Park near UOEH & 30 & $\operatorname{Prj} /$ Qus & 10 & 45 & 37 & 46 & 26 \\
\hline 46) Park near UOEH & 20 & Qus & 10 & 32 & 31 & 49 & 41 \\
\hline 47) Mizumaki & 80 & $\mathrm{Cic}$ & 15 & 38 & 32 & 86 & 62 \\
\hline 48) Mizumaki & 50 & $\mathrm{Apa} / \mathrm{Ces}$ & 18 & 48 & 42 & 99 & 1 \\
\hline 49) Takenami; Wa. & 40 & Qus/Maj & 12 & 31 & 30 & 51 & 31 \\
\hline 50) Takenami; Wa. & 40 & Bamboo & 10 & 33 & 32 & 90 & 27 \\
\hline
\end{tabular}

momum camphora, C. japonicum (Lauraceae), Elaeocarpus sylvestris (Elaeocarpaceae), Ilex rotunda (Aquifoliaceae), Aphananthe aspera (Ulmaceae), Celtis sinensis var. japonica (Ulmaceae), Prunus jamasakura (Rosaceae), Zanthoxylum ailanthoides (Rutaceae), Pinus densiflora (Pinaceae), and bamboo. The height of the canopy trees varies with stands from 6 to $25 \mathrm{~m}$, depending on the intensity of man's impact in the past and present. Their diameter also varied from $6 \mathrm{~cm}$ in young stands to $70 \mathrm{~cm}$ in matured stands (Table 1).

\section{Methods}

The vegetation of each stand was surveyed and the height and coverage of each foliage layer were recorded (1st-tree, 2nd-tree, shrub, and herb layer). The component species were listed until no additional species could be found even when the sampling area exceeded about $200 \mathrm{~m}^{2}$. Then the dominance of each species in each layer was recorded according to the Braun-Blanquet's (1964) scale ( +-5$)$.

The original data thus collected were converted to the presence-absence data. The reciprocal averaging method (Hill, 1973) (hereafter abbreviated as RA) was adopted as the method of data processing, because RA gives effectively the ordination of both stands and species at the same time with little distortion (Gauch et al., 1977). Prior to the RA calculations, the species with high presence percentages were excluded from the data table, because they have little effects on the ordination. They were all evergreen plants like Eurya japonica (Theaceae), Dendropanax trifidus (Araliaceae), Litsea sericea (Lauraceae), Symplocos lucida (Symplocaceae), Dryoteris erythrosora (Aspidiaceae), and some others. Finally, sixty species were used for the calculation. They were the species whose occurrences were between 4 to 36 out of the 50 studied stands and those that are thought of as 
indicators of environmental or successional relations in the northern Kyushu regions. The selection of these species was made based on our field experiences. Table 2 gives the presence-absence data of the sixty selected species in the fifty stands studied.

In the RA calculations, first and second axes were extracted in both the stand and species ordinations. The calculations were made according to the Hill's method (Hill, 1973) on an integer basis. The iterative calculations in the second axis was discontinued when the difference in score total was minimum (not zero) between the previous and the succeeding calculations.

\section{Results and Discussion}

The RA calculations yielded interpretable results in both the stand and species ordinations and revealed several new facts, as given below.

Stand ordination

The last two columns of Table 1 give the RA scores of stands from 0 to 100 for the first and second axes. Fig. 2 is the scatter diagram of the stands, showing the foresttypes categorized by the canopy dominants (or subdominants) (see Table 1 for the original data). The forest-types recognized are (i) the Quercus serrata forest in the bottom-left of the diagram, (ii) the Machilus thunbergii forest in the bottom-right, (iii) the Aphananthe aspera forest in the bottom-right corner and (iv) the Castanopsis cuspidata forest in the topright. Three exceptional stands are shown by open triangles in Fig. 2. No stands were plotted in the top-left of the diagram.

Fig. 3 and 4 are the scatter diagrams of the canopy height and the number of species recorded in the stands, respectively. Apparently, the canopy is higher and the number of species is more at the bottom-right and the top-right of the diagram. This fact shows that the stands at the right-hand side of the diagram are well developed forests characterized by high canopy and many species. To assure these relations, correlation coefficients between the stand RA scores and the vegetation characteristics were calculated in the gradients (1) from the bottom-left to the bottom-right (that is, from the Quercus through Machilus to Aphananthe stands), (2) from the bottom-left to the top-right (from the Quercus to Castanopsis stands), and (3) from the bottom-right to the top-right (from the Aphananthe or Machilus to Castanopsis stands). Table 3 shows the results of the correlation calculations, showing highly correlated relations between the stand RA scores and the canopy height in the gradients (1) and (2), but few correlation in (3). The correlation between the RA scores and the numbers of species is also recognized in (1) and (2) but not in (3).

Based on the results mentioned above, the Quercus-Machilus-Aphananthe series and the Quercus-Castanopsis series can be interpreted as those of the forest succession from the early to later phases. The Aphananthe-Machilus-Castanopsis series, on the other hand, cannot be 
Table 2. Presence-absence data used for RA calculation. For stand nos, see footnote

\begin{tabular}{|c|c|c|}
\hline Alpinia japonica & $1111 \ldots 1 \ldots .111 \ldots \ldots 1 \ldots 1 \ldots \ldots \ldots \ldots \ldots \ldots \ldots$ & Hanamyoga \\
\hline Cornus brachypoda & $11.111 \ldots . .1 \ldots \ldots \ldots \ldots \ldots 1 \ldots \ldots \ldots \ldots, \ldots \ldots \ldots$ & Kumanomizuki \\
\hline Aucuba japonica & $1111.111 \ldots .1 .1 \ldots \ldots \ldots \ldots \ldots \ldots \ldots \ldots$ & Aoki \\
\hline Aphananthe aspera & $1111111.11 .1 .1 \ldots 1.1 .1 \ldots \ldots \ldots \ldots \ldots \ldots . .11 \ldots \ldots$ & Mukunoki \\
\hline Celtis sinensis var. japonica & $111.111 \ldots 1 \ldots 1 \ldots \ldots 1 \ldots 1 \ldots \ldots \ldots \ldots \ldots 1 \ldots \ldots$ & Enoki \\
\hline Symplocos glauca & $1111 \ldots 11.1111 \ldots 11 . \ldots 1.1 \ldots 1.1 \ldots \ldots \ldots 11 \ldots \ldots \ldots$ & Mimizubai \\
\hline Ilex chinensis & $111 \ldots 111.1 \ldots 11 \ldots \ldots 1.11 \ldots \ldots \ldots \ldots \ldots$ & Nanamenoki \\
\hline Rumohra aristata & $\ldots 1 \ldots 1.111 \ldots \ldots 11 \ldots \ldots \ldots \ldots \ldots \ldots \ldots \ldots \ldots \ldots$ & Hosobakanawarabi \\
\hline Quercus gilva & $\ldots 1 \ldots \ldots 11 \ldots \ldots 1 \ldots \ldots \ldots \ldots \ldots \ldots \ldots \ldots \ldots \ldots$ & Ichiigashi \\
\hline Maesa japonica & $.11 \ldots \ldots .1 \ldots .11 \ldots \ldots \ldots \ldots 1, \ldots \ldots \ldots, \ldots \ldots \ldots$ & Izusenryo \\
\hline Meliosma rigida & $\ldots \ldots \ldots 1 \ldots 1 \ldots 1 . .1 \ldots \ldots \ldots \ldots, \ldots \ldots \ldots, \ldots \ldots \ldots$ & Yamabiwa \\
\hline Liriope platyphylla & $1111111111.111 \ldots 1111 \ldots 1.11 .1 .1 \ldots 1.11 \ldots \ldots \ldots \ldots$ & Yaburan \\
\hline Damnacanthus major & $\ldots \ldots 1.111 \ldots \ldots 1.1 . \ldots 1.11 .1 . \ldots \ldots \ldots \ldots, \ldots \ldots \ldots$ & Juzunenoki \\
\hline Trachelospermum asiaticum & 1111111111.1111 .11111111 .11111 1..... . . . . & Teikakazura \\
\hline Hedra rhombea & $11111111111111 \ldots 1111111.111111$ 1...111..11 $1 \ldots \ldots \ldots$ & Kizuta \\
\hline Anodendron affine & $\ldots 1 \ldots \ldots .1 \ldots 1 \ldots \ldots 1 \ldots 11.1 . \ldots \ldots \ldots \ldots \ldots \ldots$ & Sakaki kazura \\
\hline Damnacanthus indicus & 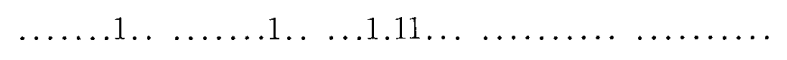 & Aridoshi \\
\hline Camellia japonica & .111111111 11.1.1111. 111111.11. 11.111.1.1 .1...... & Yabutsubaki \\
\hline Quercus glauca & $1.1 .1111 .1 \ldots 1 \ldots 1 \ldots \ldots 1.111 \ldots 11 \ldots 111 \ldots 1 \ldots 1 \ldots \ldots$ & Arakashi \\
\hline Elaeocarpus sylvestris & $\ldots \ldots 1 \ldots 11.1 \ldots 1 \ldots \ldots, \ldots \ldots \ldots 1 \ldots \ldots 11 \ldots \ldots \ldots \ldots$ & Horutonoki \\
\hline Viburnum japonicum & $\ldots \ldots 1 \ldots 1 \ldots 1 \ldots 11 \ldots \ldots 11 \ldots \ldots \ldots, \ldots \ldots \ldots$ & Hakusanboku \\
\hline Ilex buergeri & $11 \ldots 1111111.1111111$ 111111111 $111111111 . \ldots \ldots \ldots$ & Shiimochi \\
\hline Actinodaphne lancifolia & $\ldots 111 \ldots \ldots \ldots \ldots 1 \ldots 1.11 \ldots \ldots \ldots \ldots \ldots 1 \ldots \ldots$ & Kagonoki \\
\hline Ophiopogon ohwii & $11111111.1 .111 \ldots 11 \ldots 1111111111.111111 .11 .11 .1 \ldots$ & Nagabajanohige \\
\hline Fatsia japonica & 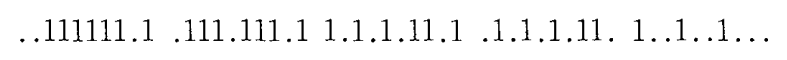 & Yatsude \\
\hline Michelia compressa & $\ldots 1 \ldots \ldots .1 \ldots .11 \ldots \ldots 1.11 .11 \ldots 1.1 \ldots 1 . \ldots \ldots \ldots$ & Ogatamanoki \\
\hline Elaeocarpus japonicus & $\ldots \ldots \ldots \ldots \ldots . . .11 .1 .111 \ldots \ldots \ldots \ldots$ & Kobanmochi \\
\hline Ilex rotunda & $\ldots 1.1 .1 .111 .11111 \ldots 1111111 \ldots 111111111.1 .11 \ldots \ldots$ & Kuroganemochi \\
\hline Ilex integra & $11.1 .1 .111 .11111111 .11111111111111111111 .11 .11 \ldots$ & Mochinoki \\
\hline Cinnamomum japonicum & $111111111.1111111 .11111111111111 . .111 .11111 .1 .11$ & Yabunikkei \\
\hline Ternstroemia gymnanthera & $\ldots \ldots \ldots \ldots \ldots 1.1 \ldots . .11111 \ldots 11 \ldots 1 \ldots \ldots \ldots \ldots \ldots$ & Mokkoku \\
\hline Stauntonia hexaphlla & 1..1.1.111 .1.1111111 1.1.111111 $11111111111111 \ldots . .1$ & Mube \\
\hline Woodwardia japonica & $\ldots \ldots \ldots \ldots \ldots \ldots 11 \ldots 111.11$.1.1.1.1. $\ldots \ldots \ldots$ & Ookaguma \\
\hline Myrsine seguinii & $\ldots \ldots \ldots \ldots \ldots 111 ., 1.1 \ldots 111.1 \ldots 1 \ldots \ldots 1 \ldots$ & Taimintachibana \\
\hline Gardenia jasminoides & $\ldots \ldots 1.1 \ldots \ldots 1 \ldots 1.111 .111111111$ 1111111.1. 1.1.1.... & Kuchinashi \\
\hline Ardisia japonica & $1.111 .11 .1 .11 .1 \ldots .11 \ldots 1.11111$ 1.11.111.1 111111.1.. & Yabukoji \\
\hline Daphniphyllum teijsmannii & 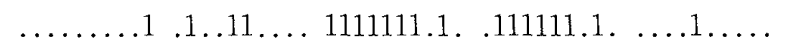 & Himeyuzuriha \\
\hline Machilus thunbergii & 11.1.111.1 111111111. 1111111.111111111111 1.11111.11 & Tabu \\
\hline Kadsura japonica & $\ldots 11 \ldots \ldots . .1 .1 .111 .11 .11111 .11$.1.1.11111 11..1.11.. & Binankazura \\
\hline Ligustrum japonicum & $.1 .11 .1 .1 . .1111111 .1 .11 .111111111111111 .11111111$ & Nezumimochi \\
\hline Clerodendron trichotomum & $\ldots \ldots \ldots \ldots \ldots .1 .1 .1 \ldots .11 \ldots 1.1 \ldots \ldots 1 \ldots .1 \ldots 1 \ldots$ & Kusagi \\
\hline Cymbidium goeringii & $1 \ldots 1 \ldots \ldots \ldots 1.1 \ldots \ldots 11.11 .11$ 1.111.1.1. 1..1111.. & Shunran \\
\hline Euscaphis japonica & $\ldots 1 \ldots \ldots \ldots \ldots \ldots \ldots 1.1 .111 .11 \ldots 1 \ldots 111 \ldots 11 \ldots$ & Gonzui \\
\hline
\end{tabular}




\begin{tabular}{|c|c|c|}
\hline Callicarpa mollis & 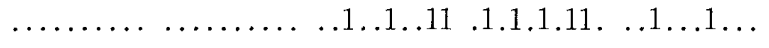 & Yabumurasaki \\
\hline Myrica rubra & $\ldots \ldots 1 \ldots \ldots \ldots \ldots \ldots \ldots 11111.1 .11 .11 .1111 \ldots 1 \ldots 11$ & Yamamomo \\
\hline Smilax china & _........1.1_.11. 1111..1111 $1111111111 . .111111111$ & Sarutoribara \\
\hline Platycarya strobilacea & $\ldots \ldots 1 \ldots \ldots \ldots \ldots \ldots \ldots \ldots 1 \ldots \ldots \ldots \ldots 1 . \ldots 1 \ldots 1 \ldots$ & Nogurumi \\
\hline Prunus jamasakura & $.1 \ldots \ldots \ldots \ldots 1.1 \ldots \ldots \ldots 1.1 \ldots \ldots 1.11 .1 .1 \ldots 1111 \ldots 11$ & Yamazakura \\
\hline Quercus salicina & $\ldots \ldots \ldots \ldots \ldots 1 \ldots \ldots \ldots 111.111 .11 \ldots 1 \ldots 11.11111 .111$ & Urajirogashi \\
\hline Mallotus japonicus & $\ldots 1 \ldots \ldots . .1 \ldots 1 \ldots \ldots \ldots \ldots 1 . .11 \ldots \ldots 1 \ldots 1.1 .1111 .1$ & Akamegashiwa \\
\hline Kalopanax pictus & $\ldots \ldots \ldots \ldots \ldots \ldots \ldots \ldots 1 \ldots \ldots \ldots 111.111 \ldots$ & Harigiri \\
\hline Zanthoxylum ailanthoides & $\ldots \ldots 1 \ldots \ldots \ldots 1 \ldots \ldots \ldots \ldots \ldots \ldots 1111 . \ldots 1.1 \ldots 1$ & Karasuzansho \\
\hline Dicranopteris linearis & $\ldots \ldots \ldots \ldots \ldots \ldots \ldots \ldots . \ldots 1 \ldots 1 \ldots 1111 \ldots . .1 \ldots 11.111$ & Koshida \\
\hline Vaccinium bracteatum & $\ldots \ldots \ldots \ldots 1, \ldots \ldots \ldots \ldots \ldots 1.1 \ldots \ldots \ldots .111 .11 .111$ & Shashanbo \\
\hline Quercus serrata & $\ldots \ldots \ldots \ldots \ldots 1 \ldots \ldots \ldots 1 \ldots \ldots \ldots .111111111111$ & Konara \\
\hline Pinus densiflora & $\ldots \ldots \ldots \ldots \ldots \ldots \ldots \ldots \ldots \ldots \ldots \ldots \ldots 11.1 . \ldots \ldots 1.11$ & Akamatsu \\
\hline Rhus javanica & $\ldots \ldots \ldots \ldots \ldots \ldots 1 \ldots \ldots \ldots \ldots \ldots \ldots 1.11 . \ldots \ldots .111$ & Nurude \\
\hline \multicolumn{3}{|l|}{ Lyonia ovalifolia } \\
\hline var. elliptica & $\ldots \ldots \ldots \ldots \ldots \ldots 1 \ldots 1 . \ldots 1 \ldots 11.1$ & Nejiki \\
\hline Miscanthus sinensis & 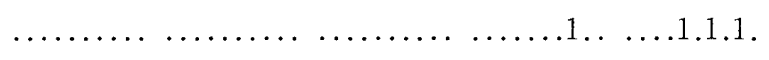 & Susuki \\
\hline Rhododendron kaempferi & & Yamatsutsuji \\
\hline
\end{tabular}

Order of stands, from left to right: $4,11,48,2,33,35,34,7,13,36,6,1,50,9,31,3,30,5,12,47,26,29$, $14,18,15,17,16,10,19,8,25,28,20,24,27,21,23,32,22,44,49,46,37,45,38,39,43,41,40,42$. (cf. Figs. 1,2 )

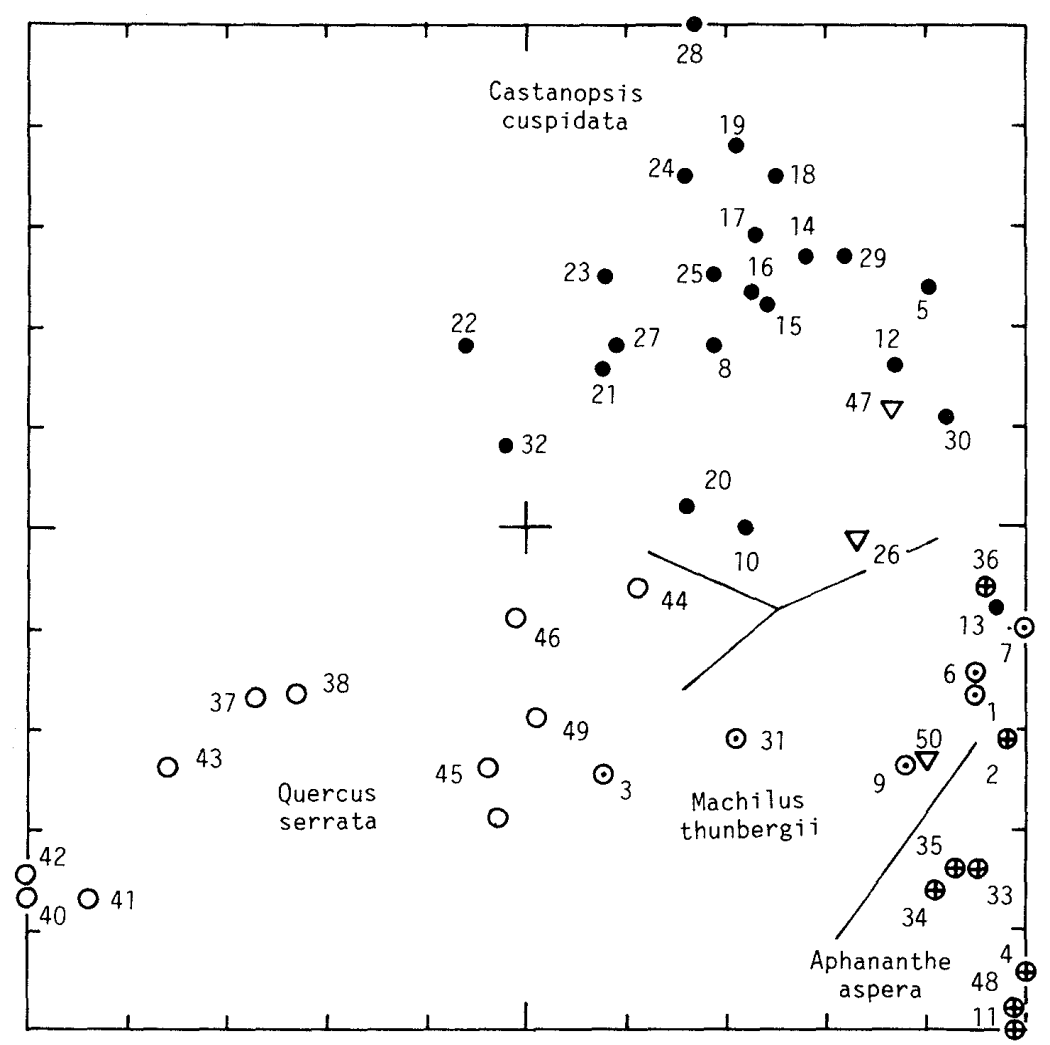

Fig. 2. Stand ordination diagram by reciprocal averaging (RA). Open circles: Quercus serratadominated stands, open circles with a point at each center: Machilus thunbergii-dominated stands, open circles with a cross: Aphananthe aspera-dominated stands, solid circles: Castanopsis cuspidata-dominated stands, triangles: abberant stands dominated by Cinnamomum japonicum (Stand 26), C. camphora (Stand 47) and bamboo (Stand 50). Numerals are the stand numbers listed in Table 1. 


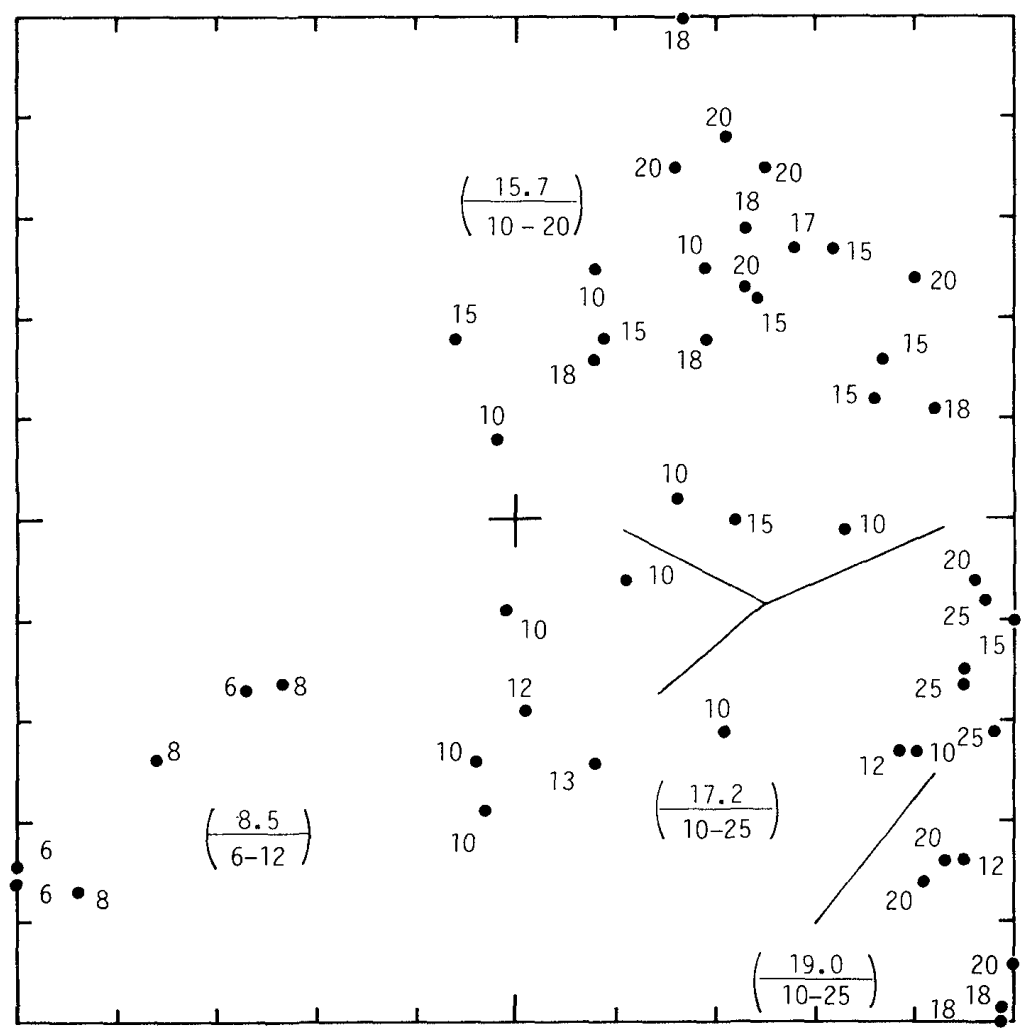

Fig. 3. Scatter diagram of canopy height $(\mathrm{m})$. Numerals in brackets mean (above) the average height and (below) the range for the forest-type.

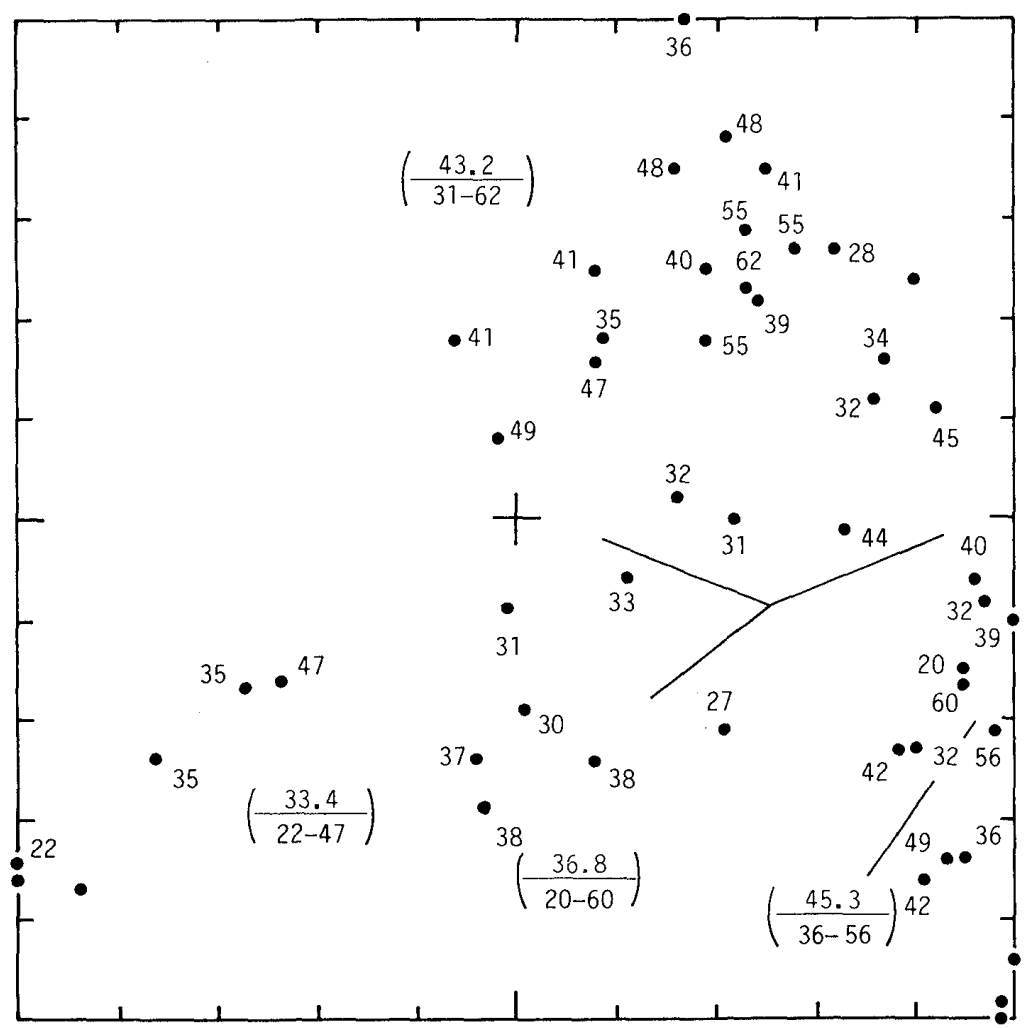

Fig. 4. Scatter diagram of the number of species found in a stand (excluding the species that occurred only in one or two stands out of fifty). Numerals in brackets show (above) the average number of species and (below) the range for the forest-type. 
considered to be a successional one but a moist to - less moist habitat gradient, because the canopy height and the number of species are not correlated with the stand RA scores.

In connection with the Aphananthe-dominated forest, Miyawaki \& Fujiwara (1974) first referred to it as a forest on the alluvial plain in Kinki district, central Honshu. Miyawaki et al. (1976) and Miyawaki (1981) described an Elaeocarpus sylvestris-Aphananthe aspera forest in Kumamoto Prefecture, and recognized it as a related but different community from the above-mentioned forest in the sense of the Braun-Blanquet's phytosociology. Ohno (1979) studied the Aphananthe aspera-Celtis sinensis var. japonica forest found in moist habitats of alluvial plains, on river banks and riverside terraces in western Honshu and Shikoku, and named it Aphanantho-Celtidetum japonicae, according to the phytosociological tradition. Miyawaki et al. (1979a, b) and Miyawaki (1982, 1983) also recognized this forest community as a potential natural community in regions west of the Kanto district of Honshu, Shikoku and Kyushu, but its actual presence has not yet been recognized in Kyushu. The present paper is the first record of the Aphananthe-Celtis forest as an existing forest community in Kyushu.

Minamikawa (1974) and Ohno (1979) considered that the Aphananthe-dominated forest was succeeded by the Machilus forest in the succession. This is a possible interpretation concerning the Aphananthe-Machilus series. We consider it to be the environmental gradient from moist to less moist habitats in lowland area, on the basis of the fact that there is no correlation between the stand RA scores and the canopy height and the number of species (see Table 3 and Figs. 3 and 4).

Species ordination

The distribution behavior of the component species can be studied by plotting their presence on the stand ordination diagram (Fig. 5) and by the RA species ordination itself (Table 4 and Fig. 6). Fig. 5 shows the distribution of 13 selected species on the stand

Table 3. Correlations between stand RA scores and vegetation characteristics

\begin{tabular}{lcc}
\hline & $\mathrm{n}$ & $\mathrm{r}$ \\
\hline Bottom-left to bottom- right & & \\
1st-axis score to canopy height & 27 & $0.797^{* *}$ \\
1st-axis score to No. of species 1) & 27 & $0.436^{*}$ \\
Bottom- left to top- right & 34 & $0.830^{* *}$ \\
Combined 1+2 axes score to canopy height & 34 & $0.514^{*}$ \\
Combined 1+2 axes score to No. of species & & \\
Bottom-right to top-right & 39 & -0.061 \\
2nd-axis score to canopy height & 39 & 0.126 \\
2nd-axis score to No. of species & &
\end{tabular}

1) Number of species excluding those occurred in one or two out of the fifty stands studied.

$* P<0.05 \quad * * P<0.01$ 


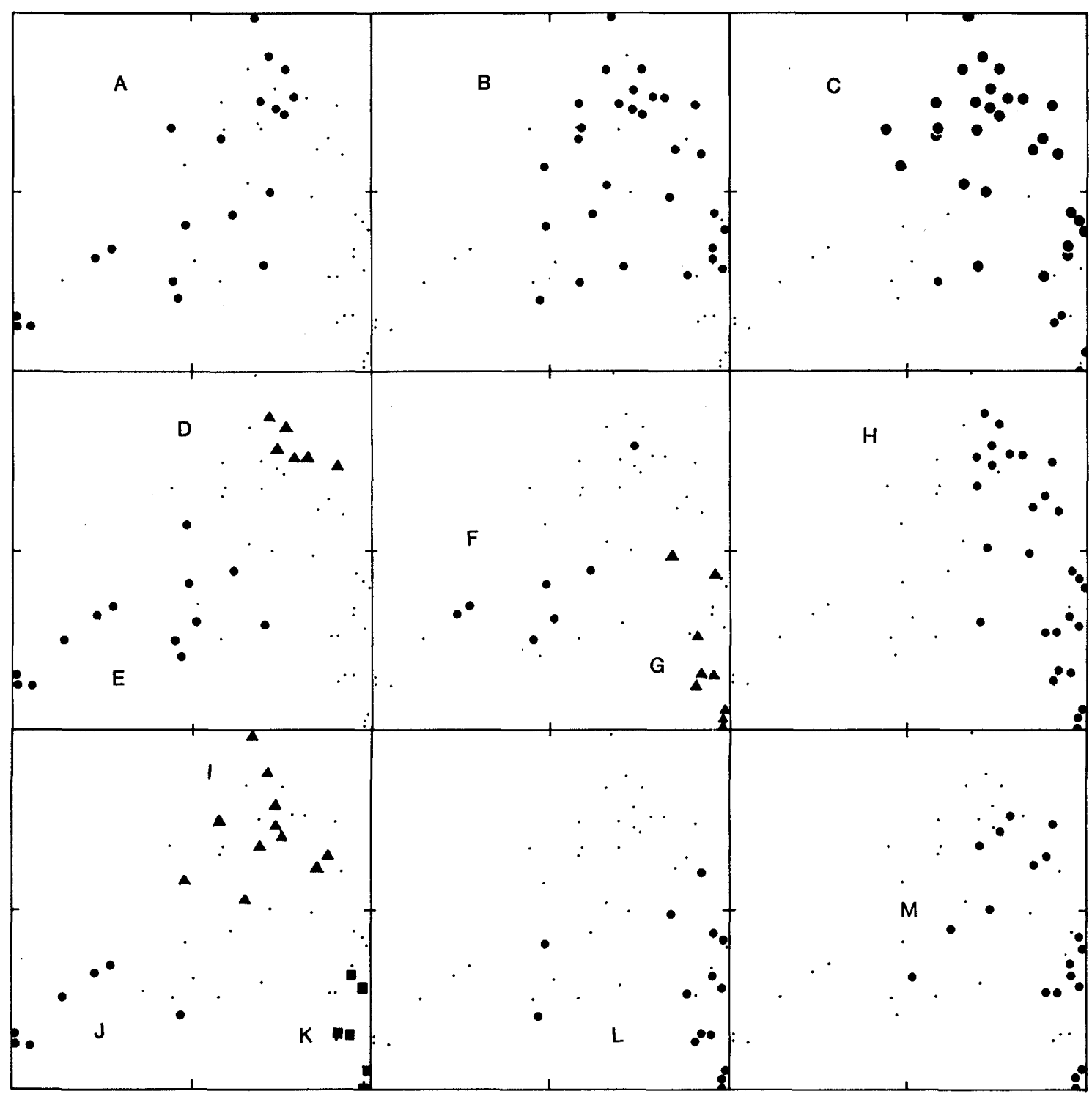

Fig. 5. Distribution behaviors of 13 selected species on the stand ordination diagram. A. Histiopteris glauca, B. Ilex rotunda, C. Castanopsis cuspidata (including var. sieboldii), D. Elaeocarpus japonicus, E. Quercus serrata, F. Kalopanax pictus, G. Celtis sinensis var. japonica, H. Trachelospermum asiaticum, I. Woodwardia japonica, J. Rhododendron kaempferii, K. Cornus brachypoda, L. Aphananthe aspera, M. Symplocos glauca.

ordination diagram.

The last two columns of Table 4 give the RA scores of the 60 selected species in the species ordination. The position of the species on the species ordination diagram indicates the distribution center in the detected vegetation gradients shown in Figs. 2, 3 and 4, and Table 2. The species plotted near the average point, which is at 65 on the first axis and 50 on the second, are those that are distributed in the central region of the ordination diagram, or those distributed through the whole vegetation.

The study of species distribution patterns in Fig. 6 and Table 2 revealed the groups of species with similar behaviors as follows. (1) Species whose distribution center is in 
Table 4. Scores of species in RA ordination on first and second axes

\begin{tabular}{|c|c|c|c|}
\hline \multirow[b]{2}{*}{ Species } & \multicolumn{2}{|c|}{ Axis } & \multirow[b]{2}{*}{ Japanese common name } \\
\hline & (1) & (2) & \\
\hline 1. Rumohra aristata & 100 & 41 & (Hosobakanawarabi) \\
\hline 2. Cyclobalanopsis gilva & 99 & 36 & (Ichiigashi) \\
\hline 3. Alpinia japonica & 98 & 14 & (Hanamyoga) \\
\hline 4. Cornus brachypoda & 98 & 9 & (Kumanomizuki) \\
\hline 5. Aucuba japonica & 97 & 3 & (Aoki) \\
\hline 6. Maesa japonica & 94 & 40 & (Izusenryo) \\
\hline 7. Meliosma rigida & 92 & 49 & (Yamabiwa) \\
\hline 8. Aphananthe aspera & 91 & 15 & (Mukunoki) \\
\hline 9. Celtis sinensis var. japonica & 91 & 7 & (Enoki) \\
\hline 10. Liriope platyphylla & 88 & 40 & (Yaburan) \\
\hline 11. Symplocos glauca & 88 & 32 & (Mimizubai) \\
\hline 12. Damnacanthus major & 88 & 70 & (Juzunenoki) \\
\hline 13. Trachelospermum asiaticum & 87 & 47 & (Teikakazura) \\
\hline 14. Ilex chinensis & 84 & 24 & (Nanamenoki) \\
\hline 15. Anoderon affine & 84 & 73 & (Sakakikazura) \\
\hline 16. Damnacanthus indicus & $84^{\prime}$ & 86 & (Aridoshi $)$ \\
\hline 17. Hedra rhombea & 83 & 49 & (Kizuta) \\
\hline 18. Camellia japonica & 81 & 56 & (Yabutsubaki) \\
\hline 19. Quercus glauca & 79 & 48 & (Arakashi) \\
\hline 20. Elaeocarpus sylvestris & 79 & 53 & (Horutonoki) \\
\hline 21. Viburnum japonicum & 79 & 77 & (Hakusanboku) \\
\hline 22. Castanopsis cuspidata & 78 & 65 & (Shii) \\
\hline 23. Actinodaphne lancifolia & 77 & 50 & (Kagonoki) \\
\hline 24. Ophiopogon ohwii & 76 & 51 & (Nagabajanohige) \\
\hline 25. Fatsia japonica & 75 & 49 & (Yatsude) \\
\hline 26. Michelia compressa & 75 & 81 & (Ogatamanoki) \\
\hline 27. Elaeocarpus japonicus & 75 & 94 & (Kobanmochi) \\
\hline 28. Ilex rotunda & 74 & 66 & (Kuroganemochi) \\
\hline 29. Ilex integra & 72 & 59 & (Mochinoki) \\
\hline 30. Cinnamomum japonicum & 71 & 46 & (Yabunikkei) \\
\hline 31. Ternstroemia gymnanthera & 70 & 100 & (Mokkoku) \\
\hline 32. Stauntonia hexaphlla & 69 & 58 & (Mube) \\
\hline 33. Woodwardia japonica & 68 & 93 & (Ookaguma) \\
\hline 34. Myrsine seguinii & 68 & 88 & (Taimintachibana) \\
\hline 35. Gardenia jasminoides & 68 & 75 & (Kuchinashi) \\
\hline 36. Ardisia japonica & 67 & 42 & (Yabukoji) \\
\hline 37. Daphniphyllum teijsmannii & 66 & 82 & (Himeyuzuriha) \\
\hline 38. Machilus thunbergii & 65 & 51 & ( Tabu) \\
\hline 39. Kadsura japonica & 63 & 62 & (Binankazura) \\
\hline 40. Ligustrum japonicum & 61 & 52 & (Nezumimochi) \\
\hline 41. Clerodendron trichotomum & 60 & 79 & (Kusagi) \\
\hline
\end{tabular}


(continued)

\begin{tabular}{|c|c|c|c|}
\hline \multirow[b]{2}{*}{ Species } & \multicolumn{2}{|c|}{ Axis } & \multirow[b]{2}{*}{ Japanese common name } \\
\hline & (1) & (2) & \\
\hline 42. Cymbidium goeringii & 58 & 57 & (Shunran) \\
\hline 43. Euscaphis japonica & 53 & 57 & (Gonzui) \\
\hline 44. Callicarpa mollis & 52 & 80 & (Yabumurasaki) \\
\hline 45. Myrica rubra & 52 & 74 & (Yamamomo) \\
\hline 46. Smilax china & 51 & 58 & (Sarutoriibara) \\
\hline 47. Platycarya strobilacea & 48 & 42 & (Nogurumi) \\
\hline 48. Prunus jamasakura & 45 & 34 & (Yamazakura) \\
\hline 49. Hicriopteris glauca & 43 & 54 & (Urajiro) \\
\hline 50. Mallotus japonicus & 41 & 32 & (Akamegashiwa) \\
\hline 51. Kalopanax pictus & 39 & 34 & (Harigiri) \\
\hline 52. Zanthoxylum ailanthoides & 35 & 46 & (Karasuzansho) \\
\hline 53. Dicranopteris linearis & 32 & 44 & (Koshida) \\
\hline 54. Vaccinium bracteatum & 30 & 18 & (Shashanbo) \\
\hline 55. Quercus serrata & 26 & 22 & (Konara) \\
\hline 56. Pinus densiflora & 19 & 41 & (Akamatsu) \\
\hline 57. Rhus javanica & 18 & 40 & (Nurude) \\
\hline \multicolumn{4}{|l|}{ 58. Lyonia ovalifolia } \\
\hline var. elliptica & 15 & 23 & (Neziki) \\
\hline 59. Miscanthus sinensis & 7 & 19 & (Susuki) \\
\hline 60. Rhododendron kaempferi & 0 & 0 & (Yamatsutsuji) \\
\hline
\end{tabular}

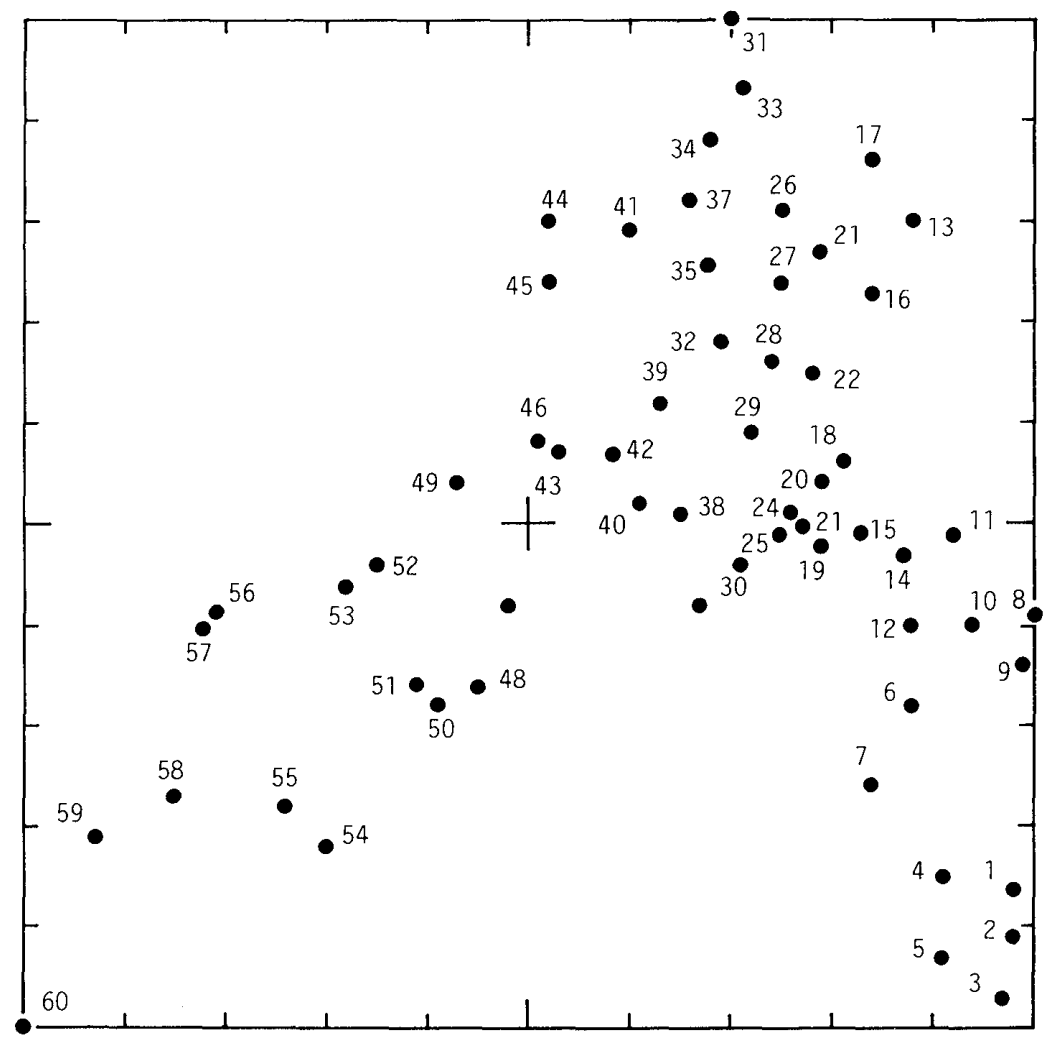

Fig. 6. Species ordination diagram by RA. Numerals are the species numbers listed in Table 4 . 
the Quercus forest (so far as the present data are concerned) are Rhododendron kaempferi, Miscanthus sinensis, Lyonia ovalifolia var. elliptica, Vaccinium bracteatum, Quercus serrata, Rhus javanica, Pinus densiflora, and Dicranopteris linearis. (2) Species whose center is in the Aphananthe forest are Aucuba japonica, Celtis sinensis var. japonica, Cornus brachypoda and Aphananthe aspera. (3) Species whose center is in both the Aphananthe and Machilus forests are Alpinia japonica, Symplocos glauca, and Ilex chinensis. (4) Species whose center is in the Castanopsis forest are Damnacanthus indicus, D. major, Anodendron affine, Elaeocarpus japonicus, Michilia compressa, Woodwardia japonica, Ternstroemia gymnanthera, Myrsine seguinii, Myrica rubra, Gardenia jasminoides, and Daphniphyllum teijsmanii. Castanopsis cuspidata is distributed over the Castanopsis and the Machilus forest but its dominant status can be seen in the former. (5) Liriope platyphylla, Trachelospermum asiaticum, Hedera rhombea, Camellia japonica, Quercus glauca and Ilex rotunda are distributed in the well-developed Aphananthe-, Machilusand Castanopsis-dominated forest. (6) Machilus thunbergii, Ilex integra, Cinnamomum japonicum, Ophiopogon ohwii, Kadsura japonica, Ligustrum japonicum are distributed nearly throughout all the stands studied.

This study was supported by Grant-in-Aid Nos. 503071 and 56030078 in 1980 and 1981 for a Special Research Project on Environmental Science, the Ministry of Education, Culture and Science, Japan.

\section{References}

Braun-Blanquet, J. (1964): Pflanzensoziologie. 3 Aufl. Springer, Wien. 865 pp.

Gauch, H. G. Jr., Whittaker, R. H. \& Wentworth, T. R. (1977): A comparative study of reciprocal averaging and other ordination techniques. J. Ecol., 65: 157-174.

Hill, M. O. (1973): Reciprocal averaging: an eigenvector method of ordination. J. Ecol., 61: 237-249. Itow, S. (1977): Studies of species composition of plant communities. In: Species Composition and Structure of Plant Communities. Asakura Shoten, Tokyo. pp. 1-75. (in Japanese)

Itow, S., Jinno, N., Kitazawa, Y. et al. (1981): Vegetation of the UOEH campus and its surrounding area with reference to conservation of campus environment. J. UOEH, 4: 323-337.

Minamikawa, M. (1974): Scientific studies on the vegetation of Nagoya City. Nagoya City, 86 pp. (in Japanese with English summary)

Miyawaki, A. (1981, ed.): Vegetation of Japan. Kyushu. Shibundo, Tokyo. 484 pp. (in Japanese with German summary)

Miyawaki, A. (1982, ed.): Vegetation of Japan. Shikoku. Shibundo, Tokyo. 539 pp. (in Japanese with German summary)

Miyawaki, A. (1983, ed.): Vegetation of Japan. Chugoku. Shibundo, Tokyo. 540 pp. (in Japanese with German summary)

Miyawaki, A. \& Fujiwara, K. (1974): Vegetation der Stadt Itami (Präfektur Hyogo). Itami. 136 pp. (in Japanese with German summary)

Miyawaki, A., Miyata, I., Suzuki, K. et al. (1976): Bericht der Vegetation des West-Teiles in der Präfektur Kumamoto, Kyushu. Kumamoto Kaihatsu Kenkyu Center, Kumamoto. pp. 1-87. (in Japanese with German summary)

Miyawaki, A., Okada, S., Fijiwara, K., et al. (1979a): Karte der potentielle natürlichen Vegetation des 
Chugoku-Gebietes (West-Honshu). 1 map. Yokohama.

Miyawaki, A., Okuda, S., Nakamura, Y. et al. (1982): Vegetation der Stadt Handa (Präfektur Aichi). Handa. 121 pp. (in Japanese with German summary)

Miyawaki, A., Suzuki, K. \& Nakata, E. (1979b): Vegetation des NO-teils der Stadt Fukuoka, Kyushu. Bull. Yokohama Phytosociol. Soc., 17: 1-103. (in Japanese with German summary)

Ohno, K. (1979): Phytosoziologische Studien über die Uferwälder auf den Alluvialebenen in WJapan. Vegetation und Landschaft, Japan. Bull. Yokohama Phytosociol. Soc., 16: 227-236. (in Japanese with German summary)

北九州市北西部および近隣地における森林植生の傾度

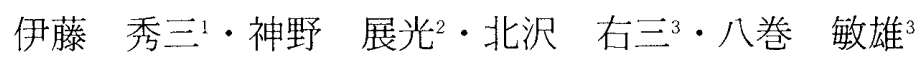

'長崎大学教養部 2 福岡教育大学 3産業医科大学生物学教室

要旨：医生ヶ丘をふくむ北九州市北西部および近隣地において，森林群落 50 スタンドを調査し た．それらを優占種により分類すると，コナラ群落，タブノキ群落，ムクノキ群落，シイ ノキ群落であった。 50 スタンド，60 種の群落資料を反復平均法により解析した結果，次 の三つの植生の系列が明らかとなった。(i)コナラ群落一タブノキ群落一ムクノキ群落，(ii) コナラ群落一シイノキ群落, (iii)夕ブノキおよびムクノキ群落一シイノキ群落. 前 2 系列は 樹高の増大および種類の増加と有意の相関をもつ森林の群落遷移の系列であり，第 3 の系 列ではそれらと相関がなく，環境傾度上の系列であることが明らかとなった。

J. UOEH（産業医大誌），6(2): 149-162 (1984) 